\title{
The Administration of Topical Aloe vera Extract Reduce the Number of Sunburn Cells and Expression of Caspase-3 on Post UVB-light- exposure Epidermis
}

\author{
Kusumawati Soetrisno ${ }^{1^{*}}$, Prasetyowati Subchan ${ }^{2}$, Atina Hussana ${ }^{3}$ \\ ${ }^{1}$ Biomedical Science Study Program, Medical Faculty, Universitas Islam Sultan Agung, Semarang \\ ${ }^{2}$ Dermatology and Venereology Study Program, Medical Faculty, Universitas Diponegoro, Semarang \\ ${ }^{3}$ Pharmacology Department, Medical Faculty, Universitas Islam Sultan Agung, Semarang \\ *corresponding author, email: k_soetrisno@live.com
}

\begin{abstract}
Introduction: Ultraviolet $B(U V B)$ radiation triggers the formation of free radicals that cause apoptosis and sunburn cells (SBC) formation. Aloe vera contains anti-inflammatory and antioxidant compounds that can potentially inhibit this process. Objective: to assess the effect of topical Aloe vera extract administration on the decrease of SBC number and Caspase-3 expression on the epidermis after UVB light exposure.

Methods: In a post-test only group design study, a single dose of 3 doses of Erythema (DEM) was performed on two groups of 6 week old BALB/c female rats. Group A (control) did not receive any topical treatment, and group B (treatment) were smeared with $75 \%$ Aloe vera extract before irradiation. Each group was divided into 4 sub-groups based on post-exposure time of 6 hours (A1 and B1), 12 hours (A2 and B2), 24 hours (A3 and B3), and 48 hours (A4 and B4). The expression of caspase-3 was assessed by immunohistochemical staining while the SBC number was measured using a microscope. The expression of caspase- 3 was analyzed using the Kruskal-Wallis and Mann-Whitney statistical tests, while the number of SBC was analyzed using the one-way ANOVA statistical test and the post-hoc LSD test.

Results: The results of the Kruskal-Wallis analysis showed a significant difference in Caspase-3 expression between groups, $p<0.05$. The results of Mann-Whitney analysis showed a significant difference in Caspase-3 expression between the A1-A3 and B1-B3 subgroups ( $p<0.05)$. One-way ANOVA analysis showed a significant difference in the number of SBC between groups $(p<0.05)$. Post-hoc LSD analysis showed significant differences in SBC counts between groups $A$ and $B$ across all subgroups, $p<0.05$.
\end{abstract}

Conclusion: Topical application of Aloe Vera extract decreased Caspase-3 expression and the number of SBC in UVB light-exposed skin.

Keywords: Ultraviolet B, Aloe Vera, sunburn cell, Caspase-3

\begin{abstract}
ABSTRAK
Pendahuluan: Radiasi ultraviolet B (UVB) memicu terbentuknya radikal bebas yang menyebabkan pembentukan sunburn cell (SBC) dan apoptosis. Aloe vera mengandung senyawa anti-inflamasi dan antioksidan yang berpotensi menghambat proses tersebut. Tujuan: menilai pengaruh pemberian topikal ekstrak Aloe vera terhadap penurunan jumlah SBC dan ekspresi Caspase-3 pada epidermis pasca paparan UVB.

Metode: Dalam penelitian post-test only group design, dilakukan penyinaran UVB dosis tunggal sebesar 3 Dosis Eritema Minimal (DEM) terhadap dua kelompok mencit betina galur Balb/c berusia 6 minggu. Kelompok A (kontrol) tidak mendapatkan pengobatan topikal apapun; dan kelompok B (perlakuan) yang dioleskan ekstrak Aloe vera 75\% sebelum penyinaran. Masing-masing kelompok dibagi menjadi 4 sub-kelompok berdasarkan waktu pasca-penyinaran 6 jam (A1 dan B1), 12 jam (A2 dan B2), 24 jam (A3 dan B3) dan 48 jam (A4 dan B4). Ekspresi caspase-3 dinilai dengan pewarnaan imunohistokimia sedangkan jumlah SBC dinilai menggunakan mikroskop. Ekspresi caspase-3 dianalisis dengan uji statistik Kruskal-Wallis dan Mann-Whitney sedangkan jumlah SBC dianalisis dengan uji statisitk one-way ANOVA dan uji post-hoc LSD.

Hasil: Hasil analisis Kruskal-Wallis menunjukkan terjadi perbedaan bermakna ekspresi Caspase- 3 di antara kelompok, $p<0,05$. Hasil analisis Mann-Whitney menunjukkan perbedaan ekspresi Caspase-3 yang bermakna antara subkelompok A1-A3 dan B1-B3 (p<0,05). Analisis one-way ANOVA menunjukkan terjadi perbedaan bermakna jumlah SBC di antara kelompok, $(\mathrm{p}<0,05)$. Analisis post-hoc LSD menunjukkan perbedaan jumlah SBC yang bermakna antara kelompok A dan B pada seluruh subkelompok, $\mathrm{p}<0,05$.

Kesimpulan: Pemberian topikal ekstrak Aloe vera berpengaruh terhadap penurunan ekspresi Caspase-3 dan jumlah SBC pada kulit yang terpapar UVB.
\end{abstract}

Kata kunci: Ultraviolet B, Aloe vera, sunburn cell, Caspase-3

\section{INTRODUCTION}

Excessive exposure to ultraviolet (UV) light, due to depleted ozone, causing premature aging and skin cancer. The impact of UV radiation on human body can be classified into two categories, namely acute and chronic effects (Pandel et al., 2013). The acute

Copyright @ 2020 Authors. This is an open access article distributed under the terms of the Creative Commons Attribution-NonCommercialShareAlike 4.0 International License (http://creativecommons.org/licenses/by-nc-sa/4.0/), which permits unrestricted non-commercial use, distribution, and reproduction in any medium, provided the original author and source are properly cited. 


\section{Soetrisno, et al.}

effects of UV exposure include erythema, changes in skin pigment, DNA damage, and suppression of the immune system (Hart and Gorman, 2013; Pandel et al., 2013; R. Sklar et al., 2013). Meanwhile, the chronic effects of exposure to UV light can include carcinogenesis and photoaging (Welsh, 2012; Battie et al., 2014). Keratinocyte cells that are exposed to UV light can experience damage and become sunburn cells (SBC) before finally experiencing apoptosis (Lee et al., 2013). Apoptosis is a cell death process triggered by DNA damage induced by free radicals. Therefore, it can be reduced or even prevented by the use of antioxidants. Aloe vera is a plant known to have an antioxidant effect, widely used as an ingredient in healing burns caused by sun exposure (Tester and Al-Ghazzewi, 2017). However, it is not yet known whether Aloe vera can reduce SBC number and apoptosis of keratinocyte cells due to exposure to UV light.

Aloe vera is currently widely used topically as a therapeutic and preventive agent on skin epithelium exposed to UV radiation (Haddad et al., 2013; de Freitas Cuba et al., 2016). The reason for using Aloe vera as a therapeutic agent is its antioxidant and antiinflammatory properties (Nejatzadeh-Barandozi, 2013; Paul et al., 2014). One of the compounds with antioxidant activity in Aloe vera is glucomannan and acemannan compounds. Amorphophallus konjac also has glucomannan compounds which have been shown to have high antioxidant effects (Liu et al., 2015). Referring to the results of this study, the use of topical Aloe vera is expected to reduce SBC number and prevent apoptosis of keratinocyte cells due to UV light exposure.

UV light can be classified into UVA (320-400 nm), UVB (280-320 nm), and UVC (100-290 nm) (Baron and Suggs, 2014). UVC rarely penetrates the skin because most of these lights are absorbed by the ozone layer. UVA has a stronger skin penetration power than UVB, but UVB is 1,000 times more erythematogenic than UVA (Watson dan Griffiths, 2019). Excessive UV light exposure can lead to sunburn cell keratinocytes. Sunburn cells that occur due to exposure to UV light can be distinguished from normal keratinocytes because they have the characteristics of solid chromatin, picnotic cell nuclei with eosinophilic cytoplasm (Armento et al., 2015). The number of SBC will increase and reach a peak at 10-24 hours after UVB light exposure and disappear within 36-48 hours after UVB light exposure (Matsumura and Ananthaswamy, 2002; Ibuki et al., 2007).

Apart from SBC, exposure to UV light also triggers the formation of reactive oxygen species (ROS) such as superoxide, hydroxyl radicals, and hydrogen peroxide (D'Orazio et al., 2013). These free radicals can bind to DNA so that it has the potential to change cell structure and function. Furthermore, UVB exposure to the epidermis can also cause permanent DNA damage to keratinocyte cells which is mediated by ROS thereby triggering apoptosis (Nys et al., 2012; Craig et al., 2018). The apoptosis process is mediated by the protein cytosolic aspartate-specific cysteine protease (Caspase). Caspase can be divided into initiators (caspase-2, caspase-8, caspase-9, and caspase10 ), executors (caspase-3, caspase-6, and caspase-7) and inflammatory (caspase-1, caspase-4, caspase5) (Julien and Wells, 2017). Caspase-3 is one of the central executor caspases that has been studied in detail. Caspase- 3 is often used in monitoring the apoptosis process in cells due to its role in DNA fragmentation (McIlwain et al., 2013; Song et al., 2015).

This study aimed to evaluate the effect of topical Aloe Vera extract on caspase-3 expression and the number of SBC exposed to UV light.

\section{METHODS}

This study was classified into a laboratory experimental research with a post-test only control group design. Thirty-two hairless female Balb/c rats aged 6 weeks weighing 20-30 grams were divided randomly into 2 groups. The first group was the control group (Group A) and the second group was the treatment group (Group B). Both groups were irradiated with a single dose of UVB 3 DEM for 30 minutes. The control group was not given any treatment, while in the treatment group $0.1 \mathrm{~mL}$ of Aloe vera gel extract with a concentration of $75 \%$ was applied to the back area. The control and treatment groups were divided into 4 subgroups based on different observation times, namely 6 hours post-radiation (sub-group A1 and B1), 12 hours post-radiation (sub-group A2 and B2), 24 hours post-radiation. (sub-group A3 and B3), and 48 hours post-radiation (sub-group A4 and B4). The Aloe Vera extract and UVB exposure were given for 7 days. The expression of caspase- 3 was assessed by the immunohistochemical staining method and then viewed under a light microscope with a magnification of 100 times. The number of SBC was calculated through a microscope with Hematoxylin-Eosin (HE) staining at 400 times magnification. The researcher calculated the number of SBC with 2 repetitions. This research has been approved by the Bioethics Committee of Medical/ Health Research, Faculty of Medicine, Universitas Islam Sultan Agung Semarang No. 110/III/2016/ Bioethical Commission. 
http://jurnal.unissula.ac.id/index.php/sainsmedika

The Administration of Topical Aloe vera Extract Reduce the Number of Sunburn Cells and Expression of Caspase-3 ...

\section{Preparation of Aloe vera Gel Extract}

Aloe vera was washed under tap water then dried in a microwave oven at $45^{\circ} \mathrm{C}$ for 3-5 days. Dried Aloe vera with a length of $50 \mathrm{~cm}, 2.5 \mathrm{~cm}$ thick was then cleaned, removed, and finely ground. The Aloe vera powder was then added with $70 \%$ ethanol and stirred for 30 minutes using a magnetic stirrer then left for 48 hours. The maceration result was filtered 3 times through a Büchner funnel coated with filter paper and collected with an Erlenmeyer flask. The filtrate was evaporated through a vacuum rotary evaporator. Furthermore, the Aloe vera extract was diluted with distilled water to reach a concentration of $75 \%$. Aloe vera extract was then applied to the skin of the back of the rats measuring $1 \times 1 \mathrm{~cm}$ thinly in group B before irradiation.

\section{UVB irradiation}

Rats were placed on a container that was 40 $\mathrm{cm}$ from the UVB light source. UVB light was emitted from a 125 -watt lamp in a single dose of 3 DEM for 30 minutes.

\section{Preparing Skin Sample Preparations}

Rats that had been exposed to UVB light were narcotized with ether and their dorsal skin tissue was taken with a size of $1 \mathrm{x} 1 \mathrm{~cm}$. Furthermore, the network was fixed with a 10\% Neutral Formalin Buffer (BFN) solution with a ratio of $1: 10$ for 2 days. The fixation results were cut to a thickness of 3-5 $\mu \mathrm{m}$ and arranged in a tissue cassette which was then put in a special basket. The baskets were dehydrated gradually in $70 \%$ ethanol, $80 \%$ ethanol, $90 \%$ ethanol, absolute ethanol, xylol, and liquid paraffin each for 2 hours. After dehydration, air extraction was carried out with a vacuum machine for 30 minutes. Then the tissue cassettes were removed and stored at $60^{\circ} \mathrm{C}$ for a while. Liquid paraffin with a temperature of $60^{\circ} \mathrm{C}$ was poured into the network until the entire network is immersed. Paraffin was frozen in the cooling machine. Paraffin blocks were stored at 20oC. Furthermore, the paraffin blocks were cut to a thickness of 3-4 pm using a microtome and placed on a slide which was then stored in an incubator at $60^{\circ} \mathrm{C}$.

\section{SBC Observation}

The skin sample was stained with HE staining. Next, the skin sample was viewed under a light microscope at 400 times magnification. Observation and calculation of SBC were carried out per 100 keratinocytes by shifting the preparations from left to right in each sub-group. SBC was seen as keratinocytes with eosinophilic cytoplasm, picnotic nuclei, and crude chromatin.

\section{Caspase-3 Immunostaining}

Paraffin blocks were deparaffinized and rehydrated gradually, namely with absolute alcohol twice for 5 minutes, $96 \%$ alcohol for 5 minutes, and $80 \%$ alcohol for 5 minutes. The sample was then washed under running water for 5 minutes. The retrieval antigen in the form of citrate buffer with $\mathrm{pH} 6$ was placed on a staining dish and heated to a high temperature to boiling (90-95oC) in a de-cloaking chamber. The slides were put in and incubated for 20-40 minutes. Next, the staining dish was removed and left to room temperature. The slides were then washed with PBS 2 times for 5 minutes each. Next, the slide preparations were blocked with endogenous peroxidase and sniper background (blue color).

The caspase- 3 antibody (primary antibody) that has been mixed with PBS ( 0.02 Molar with a ratio of 1 : $100)$ was dripped into the sample. Then the samples were incubated at $4 \mathrm{oC}$ and left for 1 night. After incubation, the samples were washed 2 times with PBS for 5 minutes each. Yellow universal link (secondary antibody) was dripped onto the sample and incubated for 15 minutes. Furthermore, the samples were washed 2 times with PBS for 5 minutes each. Samples were dripped with streptavidin (orange color) and incubated for 10 minutes. Furthermore, the samples were washed 2 times with PBS for 5 minutes each. Samples were dripped with $D A B$ and incubated for 3-5 minutes. After incubation, the samples were washed under running water for 5 minutes. The sample then received hematoxylin counterstaining and was washed under running water. Dehydration and clearing were performed using $96 \%$ alcohol for 1 minute, absolute alcohol for 1 minute, and immersed in xylol for 1 minute. Observations were made using a light microscope and positive cells were counted per 100 cells in 100 times magnification. Keratinocytes expressing caspase- 3 have a brownish nucleus whereas keratinocytes without caspase-3 nucleus/cytoplasm are bluish or brownish.

\section{Statistical analysis}

The data on caspase- 3 expression in this study were not normally distributed and not homogeneous, so the Kruskal-Wallis and Mann-Whitney statistical tests were performed. Data on the number of SBC were normally distributed and homogeneous so that the one-way ANOVA test and the LSD posthoc test were performed. The analysis result was considered significant if $\mathrm{p}<0.05$. 
Soetrisno, et al.

Table 1. Mean Caspase-3 Expression and Number of SBC in Balb/c Female Rats

\begin{tabular}{|c|c|c|c|c|c|c|c|c|}
\hline \multirow[b]{2}{*}{ Variables } & \multicolumn{8}{|c|}{ Groups } \\
\hline & $\begin{array}{c}\mathrm{A}_{1} \\
(\mathrm{n}=4) \\
(x \pm \mathrm{SD})\end{array}$ & $\begin{array}{c}\mathrm{A}_{2} \\
(\mathrm{n}=4) \\
(x \pm \mathrm{SD})\end{array}$ & $\begin{array}{c}\mathrm{A}_{3} \\
(\mathrm{n}=4) \\
(x \pm \mathrm{SD})\end{array}$ & $\begin{array}{c}\mathrm{A}_{4} \\
(\mathrm{n}=4) \\
(x \pm \mathrm{SD})\end{array}$ & $\begin{array}{c}\mathrm{B}_{1} \\
(\mathrm{n}=4) \\
(x \pm \mathrm{SD})\end{array}$ & $\begin{array}{c}B_{2} \\
(n=4) \\
(x \pm S D)\end{array}$ & $\begin{array}{c}\mathrm{B}_{3} \\
(\mathrm{n}=4) \\
(x \pm \mathrm{SD})\end{array}$ & $\begin{array}{c}\mathrm{B}_{4} \\
(\mathrm{n}=4) \\
(x \pm \mathrm{SD})\end{array}$ \\
\hline Caspase $3(\%)$ & $\begin{array}{c}2.25 \\
( \pm 0.10)\end{array}$ & $\begin{array}{c}4.65 \\
( \pm 0.30)\end{array}$ & $\begin{array}{c}2.60 \\
( \pm 0.16)\end{array}$ & $\begin{array}{c}1.05 \\
( \pm 0.19)\end{array}$ & $\begin{array}{c}0.90 \\
( \pm 0.26)\end{array}$ & $\begin{array}{c}2.65 \\
( \pm 0.10)\end{array}$ & $\begin{array}{c}1.50 \\
( \pm 0.12)\end{array}$ & $\begin{array}{c}1.20 \\
( \pm 0.16)\end{array}$ \\
\hline SBC (\%) & $\begin{array}{c}4.03 \\
( \pm 0.19)\end{array}$ & $\begin{array}{c}10.00 \\
( \pm 0.82)\end{array}$ & $\begin{array}{c}6.15 \\
( \pm 0.13)\end{array}$ & $\begin{array}{c}2.25 \\
( \pm 0.21)\end{array}$ & $\begin{array}{c}2.88 \\
( \pm 0.10)\end{array}$ & $\begin{array}{c}4.75 \\
( \pm 0.19)\end{array}$ & $\begin{array}{c}3.00 \\
( \pm 0.08)\end{array}$ & $\begin{array}{c}1.18 \\
( \pm 0.21)\end{array}$ \\
\hline
\end{tabular}

A

B

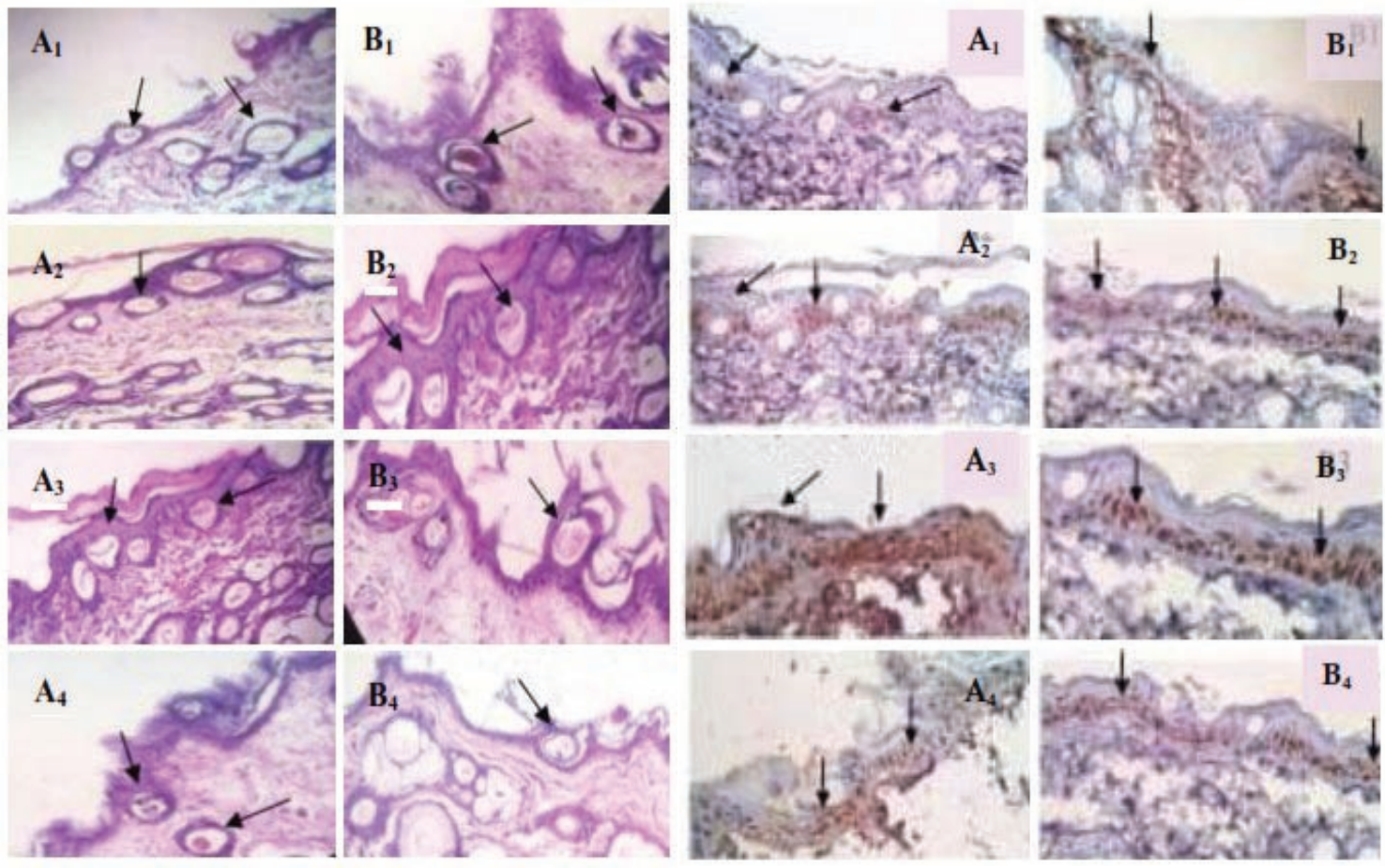

Figure 1. A. Hystophatological picture of sunburn cell was stained by Hematoxylin Eosin in each subgroups; B. Hystophatological picture of sunburn cell was stained by Immunohystochemistry in each subgroups following UVB irradiation
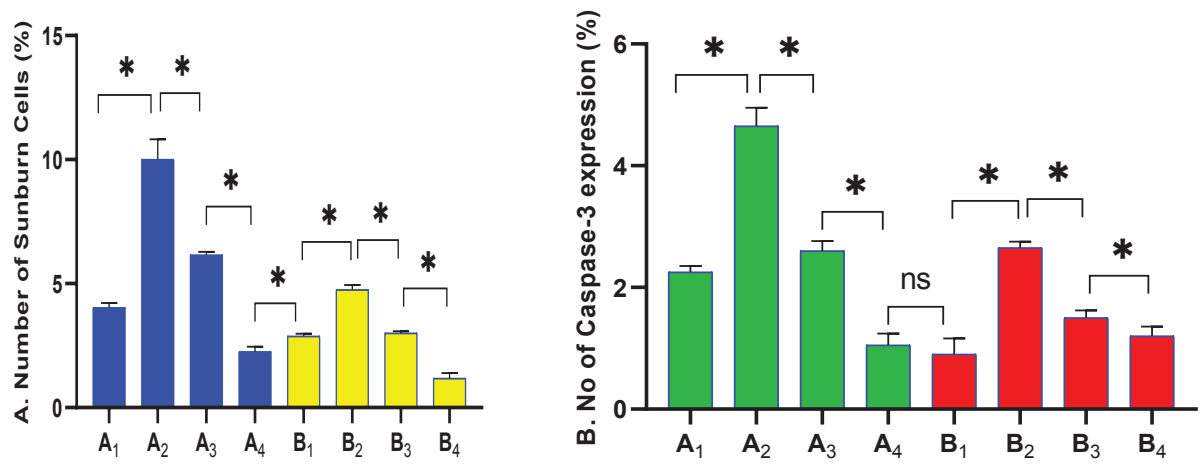

Figure 2. A. Number of sunburn cells in each groups; B. Number of caspase-3 expression in each group. Post Hoc LSD and Mann Withney analaysis: ${ }^{*} p<0.05$; ns: not significant 
http://jurnal.unissula.ac.id/index.php/sainsmedika

The Administration of Topical Aloe vera Extract Reduce the Number of Sunburn Cells and Expression of Caspase-3 ...
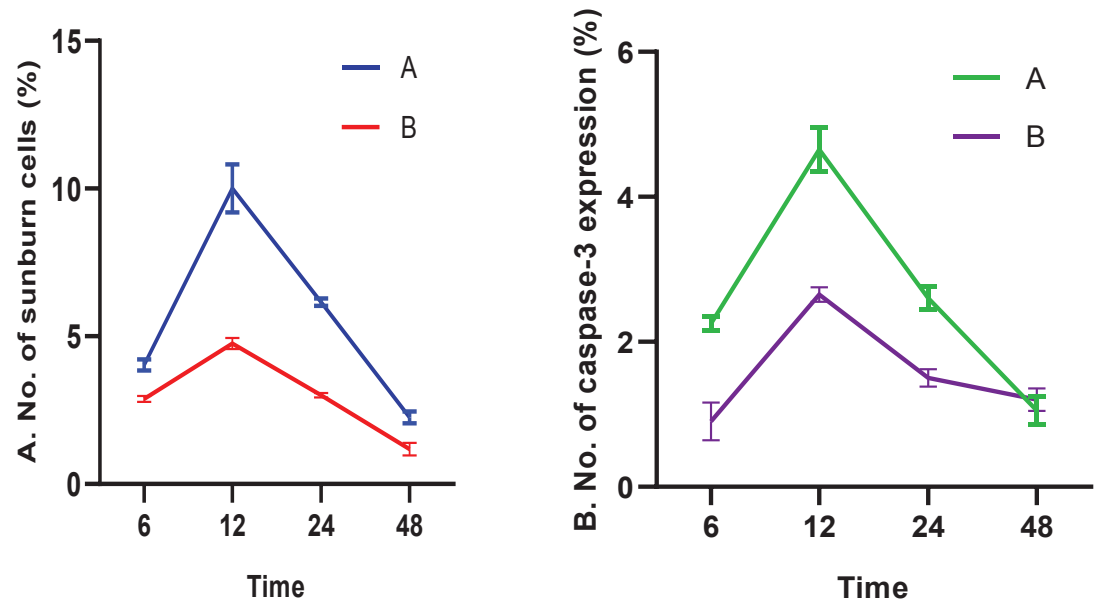

Figure 3. A. Time Dependent Effect of UVB Irradiation on SBC. B. Time dependent effect of UVB irradiation on caspase-3 expression

\section{RESULTS}

After exposure and application of topical aloe vera extract for 7 days, the results were presented in Table 1.

The results of this study indicated that the mean caspase- 3 expression and the number of SBC in all group B (B1-B4) were generally lower than group-A (A1-A4) (Figure 1A, B). Likewise, the mean in each sub-group was also different. To find out whether the difference in caspase- 3 expression and SBC count was significant, a statistical test was performed. The Kruskal Wallis test results showed that the expression of caspase3 between groups was significantly different, $p<0.05$. ANOVA test results also showed that the number of $\mathrm{SBC}$ between groups was significantly different, $\mathrm{p}<0.05$. Furthermore, to find out which groups were different, it was necessary to perform the Mann Whitney test for caspase-3 expression and Post Hoc for the number of SBC described below.

\section{The Number of Sunburn Cells}

The results of the Post Hoc analysis showed that the number of SBC in subgroup A1 was significantly lower than A2, A3, and significantly higher than A4, each with $\mathrm{p}<0.05$. On the other hand, the SBC count in subgroup A1-A4 was significantly higher than subgroup B1-B4, respectively, $p<0.05$. The number of SBC in subgroup B1 was significantly lower than $\mathrm{B} 2, \mathrm{~B} 3$, and significantly higher than $\mathrm{B} 4$, each with $\mathrm{p}$ $<0.05$. Furthermore, the SBC count in subgroup B1 was significantly lower than A1-A4, respectively $p<0.05$. The number of SBC in subgroup B4 was significantly lower than that in groups B1-B3, $p<0.05$. Meanwhile, the number of SBC in B3 was not significantly different from B1, $p>0.05$ (Figure 2A). The results of this study illustrate that the administration of topical aloe Vera can reduce the number of SBC due to exposure to UV light.

\section{Caspase-3 Expression}

The results of the Mann-Whitney analysis showed that the caspase- 3 expression in the A1 subgroup was significantly lower than A2, A3, and significantly higher than $\mathrm{A} 4, \mathrm{p}<0.05$. On the other hand, the expression of caspase-3 subgroup A1-A4 was significantly higher than subgroup B1-B4, respectively, $\mathrm{p}<0.05$. The expression of caspase-3 in subgroup B1 was significantly lower than B2, B3, $p<0.05$ and was not significantly different from $B 4, p>0.05$. Furthermore, caspase-3 expression in subgroup B1 was significantly lower than A1-A3, $\mathrm{p}<0.05$, and not significantly different than A4, $p>$ 0.05 . The expression of caspase- 3 in subgroup $B 4$ was significantly lower than both groups $\mathrm{B} 2$ and $\mathrm{B} 3, \mathrm{p}<0.05$, and was not significantly different from B1, $p>0.05$ (Figure 2B). The results of this study illustrate that the administration of topical aloe Vera can reduce caspase3 expression due to exposure to UV light.

\section{DISCUSSION}

The results of this study indicated that administration of topical Aloe vera extract could reduce caspase-3 activity in rats exposed to UVB light for 7 days. The results of this study are in line with previous studies which stated that topical application of Aloe vera has the potential to protect skin damage from UV light (Kumar et al., 2009). Referring to these results and previous studies, it can be implied that skin damage due to UV exposure is related to sunburn cells and apoptosis which is mediated by DNA damage (Nys et al., 2012; Craig et al., 2018). There were several potential 


\section{Soetrisno, et al.}

mechanisms to explain this phenomenon. First, Aloe vera can reduce the dose of UVB light received by keratinocytes so that the threshold to initiate apoptosis is not reached. Based on preliminary research on the formation of SBC, there was a threshold for a minimum UVB dose so that the apoptosis process in keratinocytes can be started (Bayerl et al., 1995; D'Orazio et al., 2013). This fact has been applied to sunscreens where several organic and non-organic compounds act as UV absorbers so that the apoptosis threshold is not reached (Gabros dan Zito, 2020). The polyphenol compounds and methanolic extracts in Aloe vera have good UV absorption properties and have been incorporated into several sunscreens (Kumar et al., 2009; Goswami et al., 2013; Ray et al., 2013). Second, Aloe vera can inhibit caspase- 3 activation through its anti-inflammatory and antioxidant properties. Many inflammatory mediators can activate apoptotic pathways such as Fas ligand and MMP-9 (Asuthkar et al., 2012; Lee et al., 2013; Yang et al., 2015). The polysaccharide and anthraquinone compounds in Aloe vera are known to inhibit the inflammatory process by inhibiting the COX pathway and reducing the MMP-9 concentration (Vijayalakshmi et al., 2012; Paul et al., 2014). Apart from inflammatory mediators, exposure to UVB light also increases oxidative compounds such as hydroxyl and superoxide groups which also activate the apoptotic pathway (Salucci et al., 2012; Lee et al., 2013). The activity of polysaccharides such as glucomannan in Amorphophallus konjac is known to have antioxidant effects (Liu et al., 2015). Therefore, Aloe vera which has the same polysaccharides is thought to reduce the production of oxidative compounds from UVB light. Third, Aloe Vera inhibits caspase- 3 by activating an apoptosis inhibitor. In the human body, the apoptosis process can be inhibited by several molecules such as Bcl-2, Bcl-x, and antioxidant compounds (superoxide dismutase, catalase, glutathione peroxidase). However, current research on the relationship between Aloe vera and Bcl-2 is still inconclusive (Shalabi et al., 2015; Yonehara et al., 2015).

The results of this study also indicated that the mean sub-group 48 hours post-radiation (sub-group A4 and B4) was not significant. These findings suggest that Aloe vera may have a time-dependent effect (Figure $3 \mathrm{~A}, \mathrm{~B})$. This is following previous studies stated that Aloe vera protection against UV was optimal in the first 24 hours post-exposure (Kumar et al., 2009). However, the time-dependent effect of Aloe vera still needs further investigation using a longer post-exposure observation time or studies studying factors that play a role in caspase- 3 expression after 48 hours post-UVB http://jurnal.unissula.ac.id/index.php/sainsmedika

irradiation. Besides, further studies are needed to see the effectiveness of Aloe vera on repeated UVB exposure.

This study showed there was a significant decrease in SBC counts between almost all control and treatment groups. This is consistent with other studies which state that SBC is formed in the first 1024 hours and disappears in 36-48 hours post-radiation (Matsumura and Ananthaswamy, 2002; Ibuki et al., 2007). The reduced SBC number in the treatment group was probably due to the antioxidant and antiinflammatory effects of Aloe vera's glucomannan and acemannan. These two polysaccharides are hydroxyl free radical scavenger compounds and can increase the expression of superoxide dismutase (SOD) and glutathione peroxidase (Vázquez-Velasco et al., 2014; Wu et al., 2014).

\section{CONCLUSION}

Application of Aloe Vera gel extract $75 \%$ can reduce the expression of caspase- 3 and the number of $\mathrm{SBC}$ in female Balb/c rats exposed to UVB radiation. Aloe Vera application has a time-dependent effect and shows the highest efficacy at 24 hours post-exposure.

\section{CONFLICT OF INTEREST}

There is no conflict of interest in this publication

\section{ACKNOWLEDGMENT}

We thank the laboratory staffs of the Center for Food and Nutrition Studies, Gadjah Mada University for their guidance in maintaining and collecting samples for this research.

\section{REFERENCES}

Armento A.J., Oldach J., Stolper G., Li M., Bachelor M.A. and Hayden P J (2015) 'Evaluation of Cutaneous Damage and Repair Following Acute Solar Ultraviolet Radiation Exposure: Experiments with an In Vitro Reconstructed Human Skin Model and Excised Human Skin', Applied In Vitro Toxicology. Mary Ann Liebert, Inc., 1(2), pp. 109-117.

Asuthkar S., Velpula K.K., Chetty C., Gorantla B. and Rao J.S. (2012) 'Epigenetic Regulation of miRNA211 by MMP-9 Governs Glioma Cell Apoptosis, Chemosensitivity and Radiosensitivity', Oncotarget, 3(11), pp. 1439-1454.

Baron E.D. and Suggs A.K. (2014) 'Introduction to Photobiology', Dermatologic Clinics. 32(3), pp. 
http://jurnal.unissula.ac.id/index.php/sainsmedika

The Administration of Topical Aloe vera Extract Reduce the Number of Sunburn Cells and Expression of Caspase-3 ...

$255-266$.

Battie C., Jitsukawa S., Bernerd F., Del Bino S., Marionnet C. and Verschoore M. (2014) 'New insights in photoaging, UVA induced damage and skin types', Experimental Dermatology, 23, pp. 7-12.

Bayerl C., Taake S., Moll I. and Jung E.G. (1995) 'Characterization of sunburn cells after exposure to ultraviolet light', Photodermatology, Photoimmunology \& Photomedicine, 11(4), pp. 149-154.

Craig S., Earnshaw C.H. and Virós A. (2018) 'Ultraviolet Light and Melanoma', Journal of Pathology, 244(5), pp. 578-585.

D’Orazio J., Jarrett S., Amaro-Ortiz A. and Scott T. (2013) 'UV Radiation and the Skin', International Journal of Molecular Sciences, 14, pp. 1222248.

de Freitas C.L., Braga F.A., Cherubini K., Salum F.G. and de Figueiredo M.A.Z. (2016) 'Topical application of Aloe vera and vitamin $\mathrm{E}$ on induced ulcers on the tongue of rats subjected to radiation: clinical and histological evaluation', Supportive Care in Cancer, 24(6), pp. 25572564.

Gabros S. and Zito P.M. (2020) 'Sunscreens and Photoprotection', in StatPearls. Treasure Island (FL): StatPearls Publishing.

Goswami P.K., Samant M. and Srivastava R. (2013) 'Natural Sunscreen Agents: A Review', Scholars Academic Journal of Pharmacy, 2(6), p. 6.

Haddad P., Amouzgar-Hashemi F., Samsami S., Chinichian S. and Oghabian M.A. (2013) 'Aloe vera for prevention of radiation-induced dermatitis: a self-controlled clinical trial', Current Oncology, 20(4), pp. e345-348.

Hart P.H. and Gorman S. (2013) 'Exposure to UV Wavelengths in Sunlight Suppresses Immunity. To What Extent is UV-induced Vitamin D3 the Mediator Responsible?', The Clinical Biochemist Reviews, 34(1), pp. 3-13.

Ibuki Y., Allanson M., Dixon K.M. and Reeve V.E. (2007) 'Radiation Sources Providing Increased UVA/UVB Ratios Attenuate the Apoptotic Effects of the UVB Waveband UVA-DoseDependently in Hairless Mouse Skin', Journal of Investigative Dermatology, 127(9), pp. 22362244 .
Julien O. and Wells J.A. (2017) 'Caspases and their substrates', Cell Death and Differentiation, 24(8), pp. 1380-1389.

Kumar M.S., Datta P.K. and Gupta S.D. (2009) 'In vitro evaluation of UV opacity potential of Aloe vera L. gel from different germplasms', Journal of Natural Medicines, 63(2), pp. 195-199.

Lee C.H., Wu S.B., Hong C.H., Yu H.S. and Wei Y.H. (2013) 'Molecular Mechanisms of UV-Induced Apoptosis and Its Effects on Skin Residential Cells: The Implication in UV-Based Phototherapy', International Journal of Molecular Sciences, 14(3), pp. 6414-6435.

Liu J., Xu Q., Zhang J., Zhou X., Lyu F., Zhao P. and Ding Y. (2015) 'Preparation, Composition Analysis and Antioxidant Activities of Konjac Oligo-glucomannan', Carbohydrate Polymers, 130. doi.org/10.1016/j.carbpol.2015.05.025.

Matsumura Y. and Ananthaswamy H.N. (2002) 'Shortterm and long-term cellular and molecular events following UV irradiation of skin: implications for molecular medicine', Expert Reviews in Molecular Medicine, 4(26), pp. 1-22.

McIlwain D.R., Berger T. and Mak T.W. (2013) 'Caspase functions in cell death and disease', Cold Spring Harbor Perspectives in Biology, 5(4), p. a008656.

Nejatzadeh-Barandozi F. (2013) 'Antibacterial activities and antioxidant capacity of Aloe vera', Organic and Medicinal Chemistry Letters, 3(1), p. 5.

Nys K., Maes H., Andrei G., Snoeck R., Garmyn M. and Agostinis P. (2012) 'Skin mild hypoxia enhances killing of UVB-damaged keratinocytes through reactive oxygen species-mediated apoptosis requiring Noxa and Bim', Free Radical Biology and Medicine, 52(6), pp. 1111-1120.

Pandel R., Poljšak B., Godic A. and Dahmane R. (2013) 'Skin Photoaging and the Role of Antioxidants in Its Prevention', ISRN Hematology. Hindawi Publishing Corporation, pp. 1-11. doi. org/10.1155/2013/930164.

Paul S., Dutta S., Chaudhuri T.K. and Bhattacharjee S. (2014) 'Anti-inflammatory and protective properties of Aloe vera leaf crude gel in carrageenan induced acute inflammatory rat models', International Journal of Pharmacy and Pharmaceutical Sciences, 6(9), p. 4. 


\section{Soetrisno, et al.}

Ray A., Gupta S.D. and Ghosh S. (2013) 'Isolation and characterization of potent bioactive fraction with antioxidant and UV absorbing activity from Aloe barbadensis Miller gel', Journal of Plant Biochemistry and Biotechnology, 22(4), pp. 483 487.

Sklar L.R., Almutawa F., Lim H.W. and Hamzavi I. (2013) 'Effects of ultraviolet radiation, visible light, and infrared radiation on erythema and pigmentation: a review', Photochemical \& Photobiological Sciences. Royal Society of Chemistry, 12(1), pp. 54-64.

Salucci S., Burattini S., Battistelli M., Baldassarri V., Maltarello M.C. and Falcieri E. (2012) 'Ultraviolet B (UVB) Irradiation-Induced Apoptosis in Various Cell Lineages in Vitro', International Journal of Molecular Sciences, 14(1), pp. 532-546.

Shalabi M., Khilo K., Zakaria M.M., Elsebaei M.G., Abdo W. and Awadin W. (2015) 'Anticancer activity of Aloe vera and Calligonum comosum extracts separetely on hepatocellular carcinoma cells', Asian Pacific Journal of Tropical Biomedicine, 5(5), pp. 375-381.

Song K., Zhang M., Hu J., Liu Y., Liu Y., Wang Y. and Ma X. (2015) 'Methane-rich saline attenuates ischemia/reperfusion injury of abdominal skin flaps in rats via regulating apoptosis level', BMC Surgery, 15(1), p. 92.

Tester R. and Al-Ghazzewi F.H. (2017) 'Role of Glucomannans in Immunology', Journal of Pharmacy \& Pharmaceutical Sciences, 20(0), pp. 97-114. http://jurnal.unissula.ac.id/index.php/sainsmedika

Vázquez-Velasco M., González-Torres L., López-Gasco P., Bastida S., Benedí J., Sánchez-Reus M.I., González-Muñoz M.J. and Sánchez-Muniz F.J. (2014) 'Liver oxidation and inflammation in $\mathrm{Fa} / \mathrm{Fa}$ rats fed glucomannan/spirulina-surimi', Food Chemistry, 159, pp. 215-221.

Vijayalakshmi D., Dhandapani R., Jayaveni S., Jithendra P.S., Rose C. and Mandal A.B. (2012) 'In vitro anti inflammatory activity of Aloe vera by down regulation of MMP-9 in peripheral blood mononuclear cells', Journal of Ethnopharmacology, 141(1), pp. 542-546.

Watson R.E.B. and Griffiths C.E.M. (2019) Cutaneous Photoaging. Royal Society of Chemistry.

Welsh J. (2012) 'Cellular and molecular effects of vitamin D on carcinogenesis', Archives of Biochemistry and Biophysics. 523(1), pp. 107-114.

Wu W.T., Yang L.C. and Chen H.L. (2014) 'Effects of konjac glucomannan, inulin and cellulose on acute colonic responses to genotoxic azoxymethane', Food Chemistry, 155, pp. 304 310 .

Yang Y., Jiang G., Zhang P. and Fan J. (2015) 'Programmed cell death and its role in inflammation', Military Medical Research, 2(12), pp. 1-12. doi.org/10.1186/s40779-015-0039-0.

Yonehara A., Tanaka Y., Kulkeaw K., Era T., Nakanishi Y. and Sugiyama D. (2015) 'Aloe vera Extract Suppresses Proliferation of Neuroblastoma Cells In Vitro', Anticancer Research. International Institute of Anticancer Research, 35(8), pp. 4479 4485 . 